\title{
Penguatan Ekonomi Mikro Berbasis Variasi Produk Olahan Sabut Kelapa
}

\author{
Dwi Haryanto \\ Fakultas Ilmu Budaya, Universitas Jember \\ Dwiharyanto.sastra@unej.ac.id
}

\author{
Hery Prasetyo \\ Fakultas Ilmu Sosial dan Ilmu Politik, Universitas Jember
}

\begin{abstract}
Abstrak
Artikel ini disusun melalui pengabdian yang memfokuskan pada ekonomi mikro yang berbasis pada pengolahan limbah sabut kelapa. Sebagai titik tolak, limbah dalam konteks ini merujuk pada bagaimana masyarakat, khususnya pengusaha kerajinan mampu memberikan nilai tambah pada sisa buah kelapa yang masih terfokus pada sabut saja. Menjadi manarik dalam hal ini, ialah persoalan bagaimana masyarakat dapat dikategorikan kedalam usaha mikro yang berbasis pada usaha rumahan. Sementara dalam konteks yang lebih makro, usaha masyarakat ini dapat dikategorikan sebagai usaha ekonomi berkelanjutan berwawasan lingkungan. Dua setting tersebut, memiliki persoalan yang perlu dikembangkan untuk menciptakan nilai tambah, inovasi dan penciptaan daya saing, sehingga mampu memperkuat perumbuhan ekonomi mikro. Melalui pendampingan, targetan pengabdian ini menitik beratkan pada adanya nilai tambah kompetitif baru yang secara sistematis dapat diarahkan pada penguatan relasi produksi yang menekankan pada modal sosial yang berakar pada struktur masyarakat.
\end{abstract}

Kata Kunci: Usaha Mikro, Nilai Tambah, Ekonomi Berkelanjutan, Inovasi, Daya Saing

\begin{abstract}
This article was prepared through a service that focused on microeconomics based on coconut fiber waste treatment. As a starting point, waste in this context refers to how people, especially handicraft entrepreneurs are able to provide added value to the rest of the coconuts which are still focused on coir. Being interesting in this matter, is a matter of how society can be categorized into microenterprises based on home-based businesses. While in a more macro context, this community effort can be categorized as an environmentally sustainable economic effort. The two settings, have problems that need to be developed to create added value, innovation and the creation of competitiveness, so as to strengthen microeconomic growth. Through mentoring, the target of this service focuses on the existence of new competitive added values which can be systematically directed at strengthening production relations which emphasize social capital rooted in the structure of society.
\end{abstract}

Keywords: Micro Business, Added Value, Sustainable Economy, Innovation, Competitiveness

\section{PENDAHULUAN}

Kabupaten Bondowoso merupakan salah satu daerah di Propinsi Jawa Timur yang memiliki wilayah yang cukup luas. Secara geografis terletak di ujung selatan pulau Jawa. Masyarakatnya bermata pencaharian mulai dari bertani hingga pengusaha. Masyarakat kawasan ini sebagian besar penghidupannya bergantung dengan memanfaatkan sejumlah hasil sumberdaya alam sekitarnya, karena kawasan pertanian dan perkebunan mempunyai sejumlah pemanfaatan hasil-hasil dari pertanian dan perkebunan tersebut.

Keberagaman pemanfaatan diwilayah ini dipengaruhi oleh sejumlah tanamantanaman hasil perkebunan salah satunya kelapa. Diantara banyak tanaman pangan, kelapa merupakan sumber makanan yang potensial karena hampir semua bagian tanaman maupun 
limbah agroindustrinya dapat dimanfaatkan. Selain itu kelapa merupakan tanaman yang mudah hidup hampir di semua jenis tanah dan tahan terhadap hama penyakit. Umumnya ditanam untuk diambil buahnya dipergunakan untuk masakan dan aneka jenis pembuatan makanan lainnya. Kelapa merupakan komoditas hasil pertanian yang banyak ditanam di Indonesia dan merupakan sumber bahan pengolahan berbagai makanan. Untuk itu perlu adanya pemanfaatan kelapa agar menjadi sesuatu yang memiliki nilai jual yang tinggi dipasaran. Kelapa tidak hanya dapat dimanfaatkan untuk membuat sayuran dan aneka jenis makanan. Salah satu bagian yang biasanya tidak terpakai bagian kulit kelapa yaitu sabut kelapa.

Sabut kelapa merupakan hasil samping dan merupakan bagian terbesar dari buah kelapa yaitu $35 \%$ dari bobot buah kelapa. Potensi produksi sabut kelapa yang memiliki nilai yang besar belum dimanfaatkan oleh masyarakat untuk kegunaan yang lebih produktif dan memiliki nilai tambah bagi masyarakat. Sebagian warga hanya memanfaatkan buah kelapa sebagai sumber pendapatan dan sumber bahan untuk melakukan berbagai olahan makanan, sementara sabut kelapa hasil dari pengupasan buah kelapa dibakar atau dibuang begitu saja tanpa ada nilai manfaatnya.

Desa Suger Lor merupakan desa yang terlatak di wilayah Kecamatan Maesan. Didesa ini banyak warga yang menggeluti berbagai kerajinan untuk keperluan rumah tangga. Salah satunya pengrajin sabut kelapa yang memanfaatkan sabut kelapa menjadi sapu. Didesa Suger Lor banyak warganya menggunakan sapu sabut kelapa disamping harganya ekonomis dan terjangkau juga ramah lingkungan. Adapun tujuan dari pengolahan sabut kelapa menjadi bentuk yang lain adalah memberdayakan masyarakat Desa Suger Lor Kecamatan Maesan sehingga dapat meningkatkan pendapatan masyarakat sekitar desa pada khususnya dan masyarakat Jember pada umumnya. Metodenya adalah mengolah sabut kelapa menjadi bahan yang mempunyai nilai ekonomis yang tinggi.

Proses pembuatan sapu dari sabut kelapa saat ini masih menggunakan metodemetode yang konvensional atau cara-cara tradisional, sehingga produk yang dihasilkan masih dalam skala home industry yang belum layak memenuhi kebutuhan pasar yang lebih global. Proses pembuatan sapu dari sabut kelapa yang masih mengandalkan cara-cara tradisional mulai proses memisahkan antara sabut kelapa (coco fiber) dan gabus (cocopeat) yang menempel pada sabut kelapa dengan cara memukul-mukulkan kayu ke kulit kelapa caracara ini masih sangat sederhana. Selain itu pola pemasaran yang dilakukan oleh industri rumahan ini masih menggantungkan pada permintaan masyarakat sekitar saja dan penjualan secara langsung melalui transaksi dari mulut ke mulut (trading by mouth to mouth). Pak. Busar selaku pengrajin dan pengolah hasil pertanian berupa sapu sabut kelapa ini tentu telah memiliki pengalaman yang cukup lama dan dapat membedakan kualitas antara sapu yang memiliki serabut yang baik dan sapu yang kurang bagus dari segi kualitasnya.

Disamping itu, ketekunan dan keuletan yang dimiliki dalam mengolah hasil pertanian berupa sapu sabut kelapa merupakan modal dasar untuk pengembangan sapu yang ramah lingkungan yang menjadi khas dari Desa Suger Lor. Pengetahuan dan pengalaman bertahuntahun untuk mengolah dan mengupayakan sapu sabut kelapa dengan cara tradisional merupakan modal dasar untuk menjaga kualitas produknya agar dapat bersaing dengan hasil-hasil kerajinan sejenis dari hasil-hasil pertanian lainnya yang terdapat di Kabupaten Bondowoso dan sekitarnya.

Peluang pemanfaatan sabut kelapa menjadi sapu yang ramah lingkungan merupakan upaya percepatan yang tidak dapat ditunda-tunda lagi. Hal ini dikarenakan produksi hasil kerajinan yang khas pada suatu kawasan pertanian dan perkebunan dipengaruhi oleh kekhasan hasil sumberdaya dikawasan daerah tersebut. Jenis sapu sabut kelapa dapat dikatakan sama dibeberapa kawasan pertanian dan perkebunan di Indonesia, akan tetapi 
keberagaman dan keadaan alam serta geografis suatu kawasan pertanian dan perkebunan merupakan hal yang membedakan produk tersebut.

Daerah Kecamatan Maesan mempunyai karakteristik daerah pertanian yang cukup luas yang utamanya digunakan untuk budidaya buah kelapa. Hal yang unik dan khas ini dapat menjadi modal dasar bagi masyarakat sekitar untuk memberikan dan menujukkan upaya pengolahan hasil samping by product melalui sapu sabut kelapa. Oleh karenanya, pola perdagangan hasil pertanian dari yang konvensional akan dikembangkan melalui pola perdagangan yang global. Pola perdagangan tersebut melibatkan unsur-unsur teknologi dalam pembuatan sapu sabut kelapa dan pola pemasaran diharapkan mampu untuk peningkatan daya usaha industri sapu sabut kelapa menjadi komoditas unggulan dari Kawasan Desa Suger Lor, kecamatan Maesan, Kabupaten Bondowoso.

\section{METODE}

Berdasarkan analisis permasalahan khususnya dalam bidang penguatan ekonomi mikro, maka tahapan -tahapan kegiatan yang akan dilaksanakan dalam program ini adalah:

* Sosialisasi bentuk program yang ditawarkan.

* Pelatihan pengetahuan peningkatan produksi pembuatan sapu sabut kelapa dengan teknologi terapan.

* Pembuatan proses produksi dengan sarana teknologi terapan pada proses pemisahan sabut dari kelapa sehingga menghasilkan serat yang lembut dan memiliki nilai jual yang tinggi.

* Pendampingan proses produksi dan pola pemasaran dalam penggunaan media online.

* Evaluasi hasil kegiatan.

\section{HASIL DAN PEMBAHASAN}

Permasalahan utama yang dihadapi oleh pengerajin adalah berkaitan dengan pengolahan produk usaha sapu sabut kelapa yang masih tradisional yaitu pemisahan sabut kelapa dari buah kelapanya yang menggunakan tangan manusia serta penjulan produk usaha sapu sabut kelapa secara konvensional atau hanya memenuhi permintaan warga sekitarnya (lokal). Oleh karenanya, hasil proses pemisahan sabut kelapa dari kelapanya masih mengalami kendala baik dalam proses jumlah kuantitas produksi yang dihasilkan maupun produk barang dagangan yang belum memiliki nilai jual yang baik dan menarik.Kualitas sapu dipasaran lokal masih relatih rendah. Rendahnya kualitas sapu dapat dilihat secara fisik belum terbentuk dengan pegangan standart dan serat yang halus.

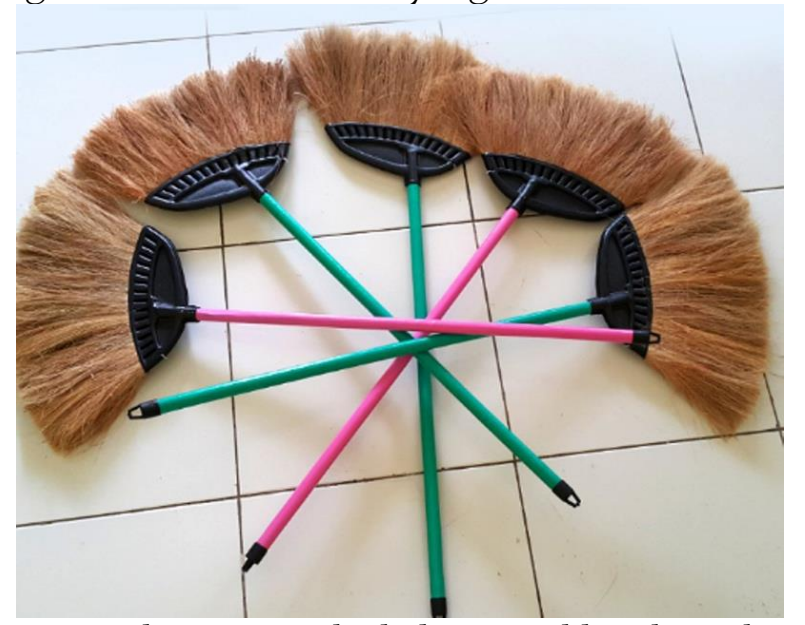

Gambar 3.1 Contoh sapu yang baik dan memiliki nilai jual yang tinggi 
Proses produksi pembuatan sapu sabut kelapa dilakukan secara sederhana. Kulit kelapa dikeringkan terlebih dahulu bisa dilakukan dengan menjemur diterik sinar matahari atau dengan cara tradisional yaitu dengan dipanaskan di tungku.
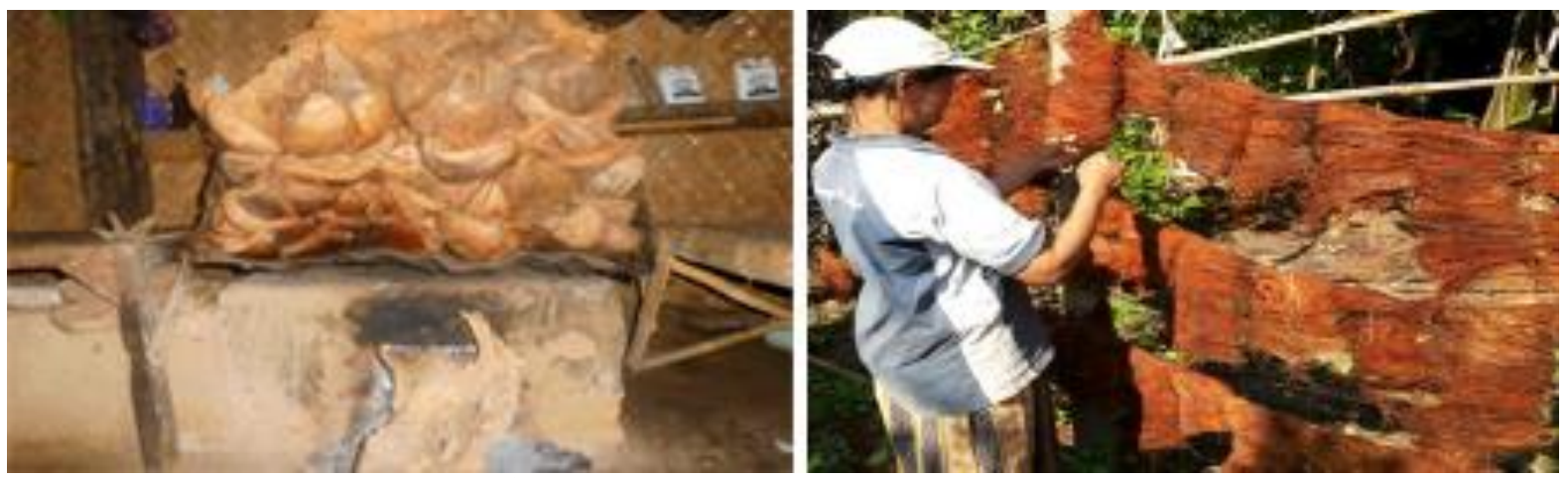

Gambar 3.2 Proses Pengeringan Sabut Kelapa

Proses selanjutnya dengan memisahkan antara sabut kelapa yang menempel pada sabut kelapa dan dengan memukul-mukul dengan peralatan yang berasal dari kayu. Proses selanjutnya merapikan serat-serat sabut kelapa agar mendapatkan serat yang lembut. Proses tersebut dilakukan secara tradisional dengan peralatan seadanya.

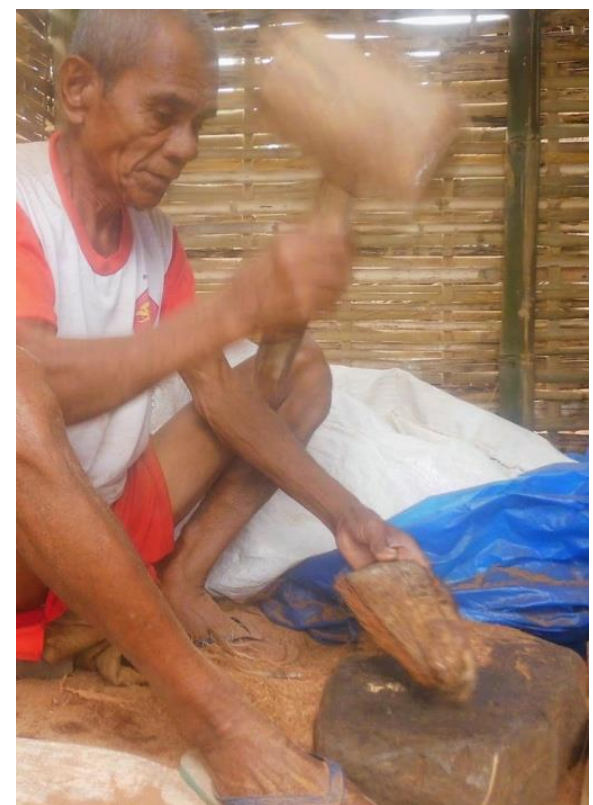

Gambar 3.3 Proses Pemisahan Sabut Kelapa dari Kelapa

Proses berikutnya proses menumbuk dan mencabuti sabut kelapa, setelah itu sabut kelapa yang sudah menyerupai rambut akan dijahit pada sebatang bambu dengan menggunakan tali rafia. Sapu yang baru diikat pada bambu masih berantakan, agar sapu terlihat lebih rapi, sapu disisir menggunakan sisir besi. Proses ini masih dikerjakan secara tradisional keadaan seperti ini membuat hasil sapu kurang menghasilkan sapu yang rapi dan standart dengan pasaran. 


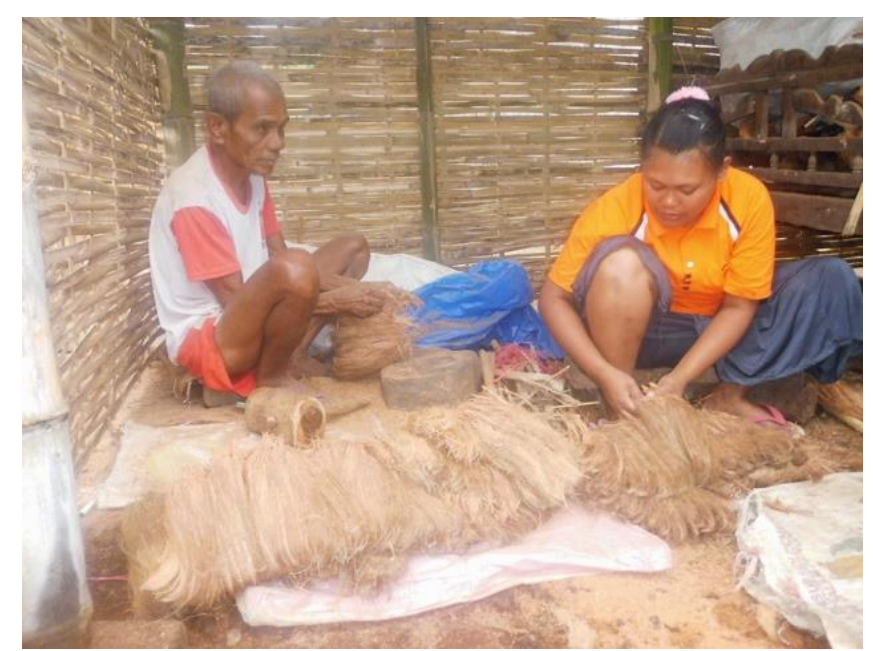

Gambar 3.4 Proses Pemisahan dan pengikatan sabut kelapa menjadi sapu

Proses pembuatan sapu selanjutnya mengikat sabut kelapa yang sudah tertata rapi kemudian di tali pakai tali rapia dan pegangannya masih sederhana dengan menggunakan bambu yang secara ekonomi belum memiliki nilai jual.

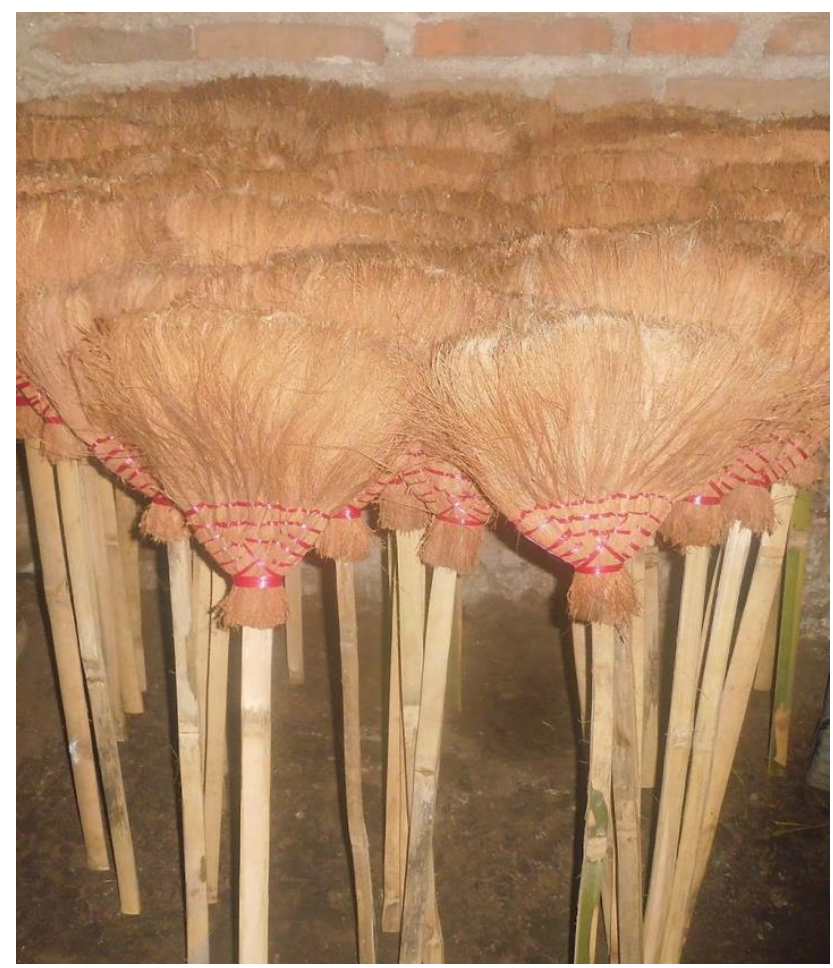

Gambar 3.5 Sapu yang telah jadi dan siap dipasarkan

Mitra menyebutkan bahwa kesulitan pada saat melakukan pemisahan sabut kelapa yang kebanyakan serat yang didapatkan hanya sedikit dari satu buah kelapa, apabila hanya mengandalkan tenaga manusia maka hasil yang didapat serat sabut kelapa kurang bagus dari segi kualitasnya. Selain itu, kesulitan berikutnya adalah pada proses penyatuan sabut kelapa yang tidak bisa rapi hal ini disebabkan sabut kelapa yang dihasilkan panjang pendeknya tidak bisa sama sehingga sulit untuk dibentuk menjadi sapu. Kurangnya pemahaman dan pengetahuan tentang pemanfaatan informasi teknologi dalam pemasaran menjadi permasalahan bagi industri rumahan (home industry) seperti home industri sapu sabut kelapa 
ini, sehingga pola pemasaran yang masih tradisional membuat proses pemasaran dan perdagangan menjadi sangat lambat dan susah untuk berkembang.

Terkait dengan permasalahan proses produksi dalam hal ini proses pemisahan dan penyatuan sabut kelapa menjadi sapu, maka akan ditawarkan solusi untuk berfokus pada pemanfaatan teknologi untuk merancang dan memodifikasi alat-alat tersebut dengan menggunakan alat bantu mesin agar tercapai bentuk dan kualitas produk yang lebih optimal dan mengembangkan alat pemisah sabut kelapa yang lebih terukur dan efisien sehingga diperoleh bentuk dan serat yang memiliki ukuran yang sama dan serat yang lebih lembut, hal ini akan lebih memudahkan untuk melakukan perdagangan. Solusi berikutnya untuk mengatasi pola perdagangan maka akan ditawarkan baik melakukan secara offline melalui pasar-pasar tradisional dan modern maupun secara online. Pola pemasaran ini akan dapat melakukan penetrasi pasar yang lebih terarah sehingga produk perdagangan dapat dipantau dari bagian produksi hingga ke hilir ke bagian pemasaran.

Sebagai strategi penguatan ekonomi mikro, pola pemasaran produk menjadi persoalan yang perlu direkayasa. Dimana pendekatan dan integrasi produk kerajinan rumah tangga dengan teknologi digital menjadi suatu keharusan. Karenanya asumsi yang dikembangkan dalam pengabdian ini meliputi pada:

1. Pemasaran Produk Secara Online

Pola pemasaran produk melalui media-media apa saja yang dapat digunakan para produsen meningkatnya pengunaan internet oleh masyarakat dewasa ini yang terjadi setiap harinya ternyata tidak dapat diabaikan begitu saja oleh para pelaku bisnis atau pengusaha. Pada saat ini banyak pelaku usaha dan bisnis memanfaatkan fasilitas yang dapat digunakan untuk memasarkan produk atau jasanya dengan membuat website, blog atau akun facebook, twiter, whatshap. Kemajuan tersebut dirasa bermanfaat besar sebagai salah satu strategi pemasaran produk barang dan jasa.

Pemasaran usaha melalui internet neruapakan salah satu cara untuk memperluas jangkauan pasar. Salah satu caranya melalui internet marketing, informasi produk-produk dalam hal ini kopi dapat menjangkau konsumen yang ada didaerah tanpa harus terjun langsung ke daerah tersebut untuk mempromosikan produk. Strategi pemasaran yang akan dilakukan untuk meningkatkan penjualan kopi biji salak melalui internet marketing yaitu Website marketing dan email marketing.

2. Website Marketing

Perkembangan teknologi belakangan ini banyak para pelaku usaha offline sengaja beralih untuk memasarkan produknya melalui media online. Salah satu media yang dimanfaatkan yaitu Website dimana tempat memberikan informasi mengenai produk kepada calon oembeli (konsumen), sehingga para konsumen dapat mengetahui kelebihan dan kekurangan produk tanpa harus datang langsung ke tempat usahanya. Selain itu website juga menjadi sarana bagi konsumen yang ingin melakukan pemesanan produk serta mempermudah pemasaran produk dengan melayani secara online atau transfer via bank, kemudian barang akan dikirimkan kepada konsumen melalui jasa pengiriman barang seperti Pos, Tiki dan JNE. Dengan adanya website marketing, pemasaran produk dapat dilakukan otomatis menggunakan bantuan sistem internet. Menanyakan produk tersebut melalui telepon, sms maupun email. Keberadaan email marketing mendukung kegiatan pemasaran baik secara online maupun offline.

3. Pola Pemasaran Produk Melalui Teknologi Audio Visual

Teknologi audio visual begitu berperan untuk menawarkan barang dan jasa salah satunya adalah iklan. Iklan merupakan media informasi yang dibuat sedemikian rupa agar dapat menarik minat khalayak, orisinal, serta memiliki karakteristik tertentu dan persuasif sehingga para konsumen atau khalayak secara suka rela terdorong untuk melakukan sesuatu 
tindakan sesuai dengan yang diinginkan pengiklan. Pembuatan iklan audio visual bertujuan untuk memperkenalkan identitas produk yang diinformasikan dan menjelaskan perbedaan produk dengan yang lain dan mengkomunikasikan konsep produk, yaitu manfaat dan kelebihannya dari segi fungsional, psikologis, atau nilai pasar.

Kegiatan pelatihan mengenai materi manajemen pemasaran yang disampaikan oleh Dien Vidia Rosa, S.Sos., M.A. Pemateri menyampaikan materi mengenai pentingnya produk dan pemasaran harus dilakukan dengan cara bersamaan dan tidak boleh terpisahkan kedua proses tersebut. Dijelaskan bahwa kegiatan memproduksi sebuah barang dalam hal ini sapu sabut kelapa juga diimbangi dengan memasarkan produk tersebut, dengan tujuan supaya produk yang dihasilkan dapat dikenal dan tersebar luas dikalangan masyarakat.

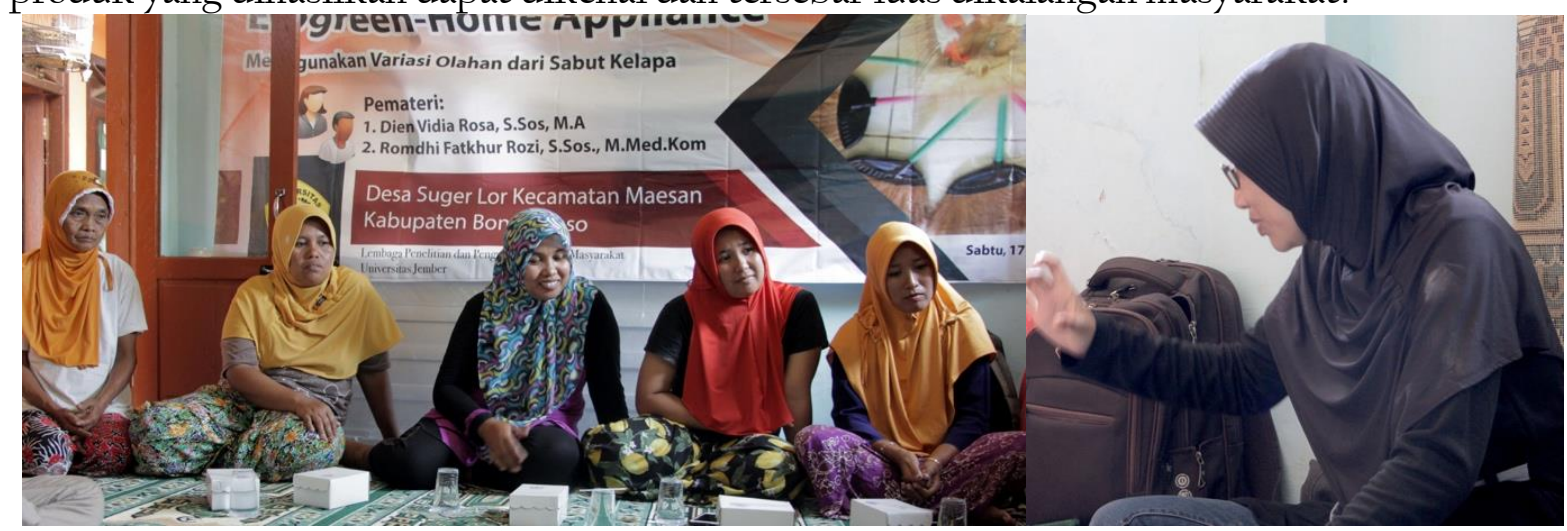

Gambar 3.6. Penyampaian materi manajemen pemasaran

Pemaparan materi selanjutnya terkait dengan inovasi yang dijelaskan bahwa inovasi sebagai terobosan yang berkaitan dengan produk-produk baru. Namun Kotler (2004) menambahkan bahwa inovasi tidak hanya terbatas pada pengembangan produk-produk atau jasa-jasa baru. Inovasi juga termasuk pada pemikiran bisnis baru dan proses baru. Menurut Buchari (2004) inovasi berarti mengamati konsumen untuk menemukan dan memuaskan konsumennya dengan memberikan produk yang baru. Sapu yang dikembangkan oleh kelompok pusaka masih tergolong kedalam sapu yang sederhana sehingga tidak memiliki nilai jual yang tinggi sehingga diperlukan sebuah inovasi untuk mengembangkan sapu sabut kelapa komoditas yang laku dipasaran. Inovasi bisa menghasilkan pertumbuhan lebih cepat, meningkatkan segmen pasar, dan menciptakan posisi korporat yang lebih baik. Pemaparan materi oleh Dien Vidia Rosa, S.Sos., M.A diikuti dengan penuh antusias oleh para peserta yang mayoritas ibu-ibu rumah tangga di Suger Lor kecamatan Maesan Bondowoso. Hal ini terbukti dengan beberapa pertanyaan yang dilontarkan oleh peserta terkait dengan pola-pola promosi dijaman yang serba canggih seperti sekarang ini. Begitu juga dengan mengenai manajemen pemasaran mulai dari perencanaan hingga evaluasi.

Kegiatan sesi II adalah penyampaian materi tentang pemasaran produk melalui teknologi audio dan internet oleh Romdhi Fatkhur Rozi, S.Sos. M.Med. Kom. Didalam pemaparannya pemateri menyampaikan mengenai media-media apa saja yang dapat digunakan para produsen makanan untuk untuk memperkenalkan produk kepada masyarakat dan menjelaskan terkait dengan market place. Marketplace adalah sebuah lokasi jual beli produk dimana seller dan juga konsumen bertemu di suatu tempat. Seller akan menjual barangnya di lapak yang sudah disediakan oleh e-commerce dengan konsep marketplace. Barang yang dijual di marketplace tersebut kemudian akan diiklankan oleh pihak e-commerce untuk mendapatkan konsumen yang potensial. Kesuksesan e-commerce dengan konsep marketplace ini ditentukan oleh banyaknya jumlah seller dan juga konsumen yang bergabung di website e-commerce tersebut. Salah satu contoh market place yang terkenal di Indonesia yaitu Bukalapak dan Tokopedia. 


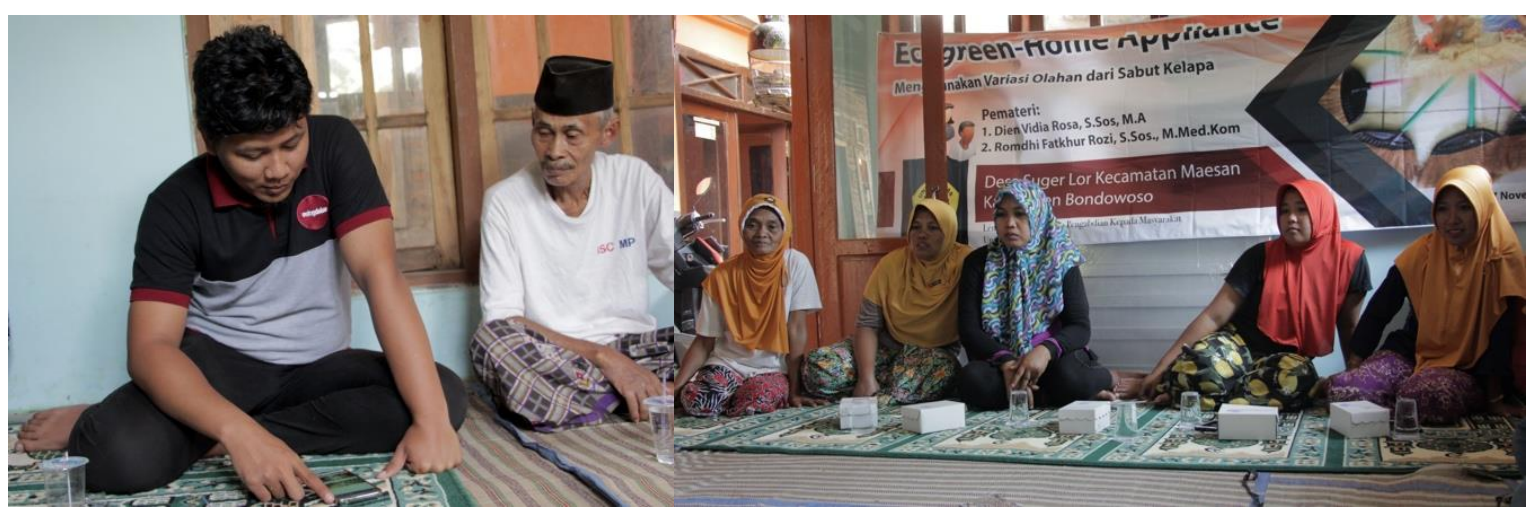

Gambar 3.7 Pemateri memberikan pelatihan terkait dengan marketplace

Romdhi Fatkhur Rozi menjelaskan mengenai marketplace yang dapat dimanfaatkan melalui fitur-fitur yang telah tersedia di handphone yang dimiliki oleh para ibu-ibu kelompok usaha sabut kelapa. Dengan mempunyai marketplace, para para produsen kerajinan sapu sabut kelapa dapat memperoleh banyak ide yang didapat dari berbagai sumber yang memberikan komentar atas tulisan yang kita terbitkan di marketplace. Sudah banyak orang-orang yang meraih kesuksesan hanya dengan memiliki sebuah marketplace, karena marketplace bersifat terbuka bagi siapa saja sehingga dapat juga dijadikan sebagai sarana untuk mempromosikan produk sapu sabut kelapa secara online. Kecanggihan teknologi saat ini seharusnya mampu menjembatani keterbatasan pengetahuan bermanfaat antar sesama, jadi gunakanlah secara bijak. Marketplace dalam hal ini dapat digunakan untuk mempromosikan produk sapu sabut kelapa kepada masyarakat luas sehingga masyarakat akan mengenal produk kerajinan ini secara luas.

Mesin yang diperbantukan untuk membuat gagang sapu yaitu mesin bubut yang dapat mengolah kayu atau woor work machinery, mesin ini digunakan secara khusus untuk membentuk atau membuat balok kayi menjadi bulat silnder atau rounded dengan diameter yang bisa disesuaikan sesuai kebutuhan, biasanya diameter gagang stick yang digunakan adalah diameter $10-60 \mathrm{~cm}$.

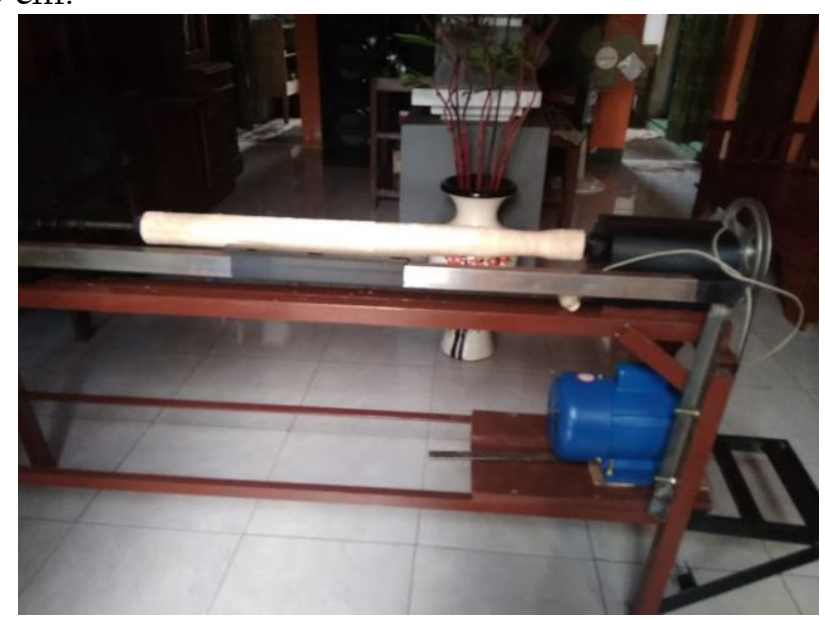

Gambar 3.8 Mesin Bubut pembuat gagang sapu

Peralatan diatas dihibahkan untuk membantu membuat gagang kayu terutama digunakan untuk konstruksi batangan kayu, tiang bulat, dekorasi furniture atau dekorasi untuk pengolahan kayu melingkar. Dengan adanya pemberian peralatan ini diharapkan agar mitra dapat berinovasi membuat produk sapu dengan gagang yang memiliki nilai jual yang tinggi sehingga dapat meningkatkan penjualan yang pada akhirnya meningkatkan pendapat mitra pengabdian 


\section{PENUTUP}

A. Kesimpulan

Tim pelaksana pengabdian masyaraat melihat adanya daya semangat masyarakat yang secara social dapat dikembangkan menjadi seperangkat modal sosial dan meningkatkan daya saing. Masyarakat yang secara tradisional mampu melihat adanya nilai yang dapat dihasilkan dari limbah sabut kelapa. Hal ini yang secara konseptual menjadi salah satu bentuk real dari ekonomi berkelanjutan berwawasan lingkungan, yang tidak lagi melihat limbah sebagai sampah yang dibung percuma, tetapi mampu diolah dan dipergunakan untuk meningkatkan ekonomi masyarakat.

\section{B. UcapanTerimakasih}

Terima kasih kepada Universitas Jember yang telah mendanai pengabdian masyarakat ini ini melalui Hibah Pengabdian kepada Masyarakat skim Program Pengabdian Kemitraan dengan pendanaan DIPA Universitas Jember tahun anggaran 2018.

\section{DAFTAR PUSTAKA}

Belch, GE, 2003, Advertising and Promotion - an Integrated Marketing Communication Prespective, $6^{\text {th }}$ Edition, McGraw Hill, New York

Ernestina M, 2008, Improving antioxidant activity and nutritional component of Philippine saltfermented shrimp paste through prolonged fermentation, Food Chemistry $111: 72-77$

Sharif, 2008, Toxicological Evaluation of Some Malaysian locally processed raw food product, Food and Chemical Toxicology, 46, 368-374.

Magnadi RH, 2011, Peran Perguruan Tinggi dalam Membangun "City Branding" yang berkelanjutan: Sebuah Upaya untuk Mendorong Pertumbuhan Perekonomian Daerah", Proceeding-Social, Ekonomi, dan Humaniora, Vol. 2, No. 1 p. 281-290 